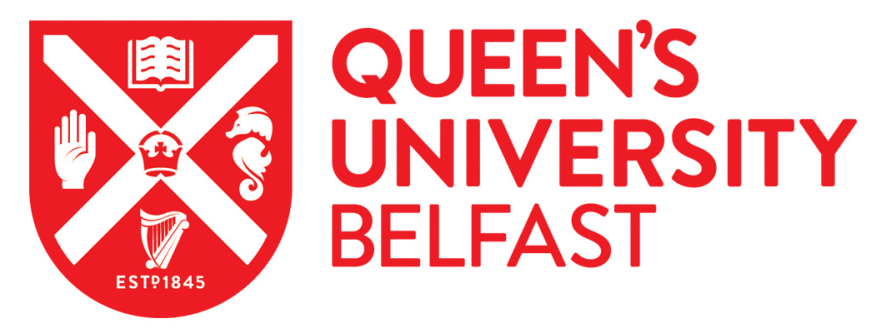

\title{
Inter-annual Arcellinida (testate lobose amoebae) assemblage dynamics within lacustrine environments
}

Nasser, N. A., Cullen, J., Patterson, C. W., Patterson, R. T., Roe, H. M., \& Galloway, J. M. (2019). Inter-annual Arcellinida (testate lobose amoebae) assemblage dynamics within lacustrine environments. Limnologica, 76, 6071. https://doi.org/10.1016/j.limno.2019.03.006

\section{Published in:}

Limnologica

\section{Document Version:}

Peer reviewed version

Queen's University Belfast - Research Portal:

Link to publication record in Queen's University Belfast Research Portal

\section{Publisher rights}

Copyright 2019 Elsevier.

This manuscript is distributed under a Creative Commons Attribution-NonCommercial-NoDerivs License

(https://creativecommons.org/licenses/by-nc-nd/4.0/), which permits distribution and reproduction for non-commercial purposes, provided the author and source are cited.

\section{General rights}

Copyright for the publications made accessible via the Queen's University Belfast Research Portal is retained by the author(s) and / or other copyright owners and it is a condition of accessing these publications that users recognise and abide by the legal requirements associated with these rights.

Take down policy

The Research Portal is Queen's institutional repository that provides access to Queen's research output. Every effort has been made to ensure that content in the Research Portal does not infringe any person's rights, or applicable UK laws. If you discover content in the Research Portal that you believe breaches copyright or violates any law, please contact openaccess@qub.ac.uk. 


\section{Inter-Annual Arcellinida (testate lobose amoebae) Assemblage Dynamics}

within Lacustrine Environments

Nasser, N.A. ${ }^{a^{*}}$, Cullen, J.a,1, Patterson, C.W. ${ }^{\mathrm{a}}$ Patterson, R.T.a , Roe, H.M. ${ }^{\mathrm{b}}$, Galloway, J.M . $^{\mathrm{a}}$

${ }^{\text {a }}$ Department of Earth Sciences, Carleton University, Ottawa, Ontario, Canada K1S 5B6

b School of Natural and Built Environments, Queen's University, Belfast, United Kingdom BT7 1NN

${ }^{\mathrm{c}}$ Geological Survey of Canada / Commission géologique du Canada - Calgary, Alberta, Canada T2L 2A7

Corresponding Author: Nawaf A. Nasser ${ }^{1}$

Address: 1125 Colonel By Drive, Ottawa, ON K1S 5B6, Canada

Email address: Nawaf.nasser@carleton.ca

ORCID: 0000-0001-9057-3248

${ }^{1}$ Current Address: School of Environmental Sciences, University of Guelph, Guelph, ON, Canada NIG2W1 


\begin{abstract}
Arcellinida (testate lobose amoebae) were examined from 22 surface-sediment samples collected from homogenous environments in eastern Canadian lakes (Lac du Castor Blanc, SW Quebec; Oromocto Lake, SW New Brunswick) to: 1) evaluate the faunal consistency of assemblages within the targeted environments; and, 2) assess the Arcellinida assemblage response evident in samples collected from Oromocto Lake in $2010 \mathrm{CE}(n=10)$ and 2012 $\mathrm{CE}(n=6)$ to inter-annual changes in environmental conditions. Cluster analysis and detrended correspondence analysis (DCA), redundancy analysis (RDA), and Bray-Curtis Dissimilarity Matrix (BCDM) were used to identify the dominant arcellinidan assemblages, determine physicochemical controls over the Arcellinida distribution, and assess the assemblages' faunal homogeneity, respectively. Cluster analysis, DCA, and BCDM results revealed two distinct and relatively homogenous arcellinidan assemblages: 1) Lac du Castor Blanc Assemblage; and 2) Oromocto Lake Assemblage, which could further be subdivided into Oromocto Lake 2010 CE (OL10), and 2012 CE (OL12) sub-assemblages. RDA results showed that $65.6 \%$ of the variance in the arcellinidan distribution could be attributed to four significant parameters; sand size fraction (32.1\%), calcium (29.2\%), manganese (2.7\%), and organic content (1.5\%). The OL10 and OL12 sub-assemblages aligned well with the respective sample collection dates of $2010 \mathrm{CE}$ and 2012 CE, with proportions of the healthy-lake-indicating Diffluggiid taxa being higher in OL12, likely due to a concurrent slight increase in substrate organic content in the $2012 \mathrm{CE}$ sediments. Our results confirm the faunal homogeneity of assemblages in limnologically similar environments, and demonstrate the rapid response of Arcellinida assemblages to changes in lake conditions at inter-annual time scales.
\end{abstract}

Keywords: Lakes, homogenous environments, Arcellinida, assemblage dynamics, inter-annual change, multivariate statistics 


\section{Acknowledgements}

The authors would like to thank the New Brunswick Alliance of Lakes Association and the Oromocto Lake Association for their ongoing support. Appreciation is also extended to J.J. Wang, Nano Imaging Facility in Carleton University for assistance in obtaining SEM images. Funding for this research project was provided by NSERC Discovery (RGPIN 05329) and Carleton University Development grants (182438) awarded to RTP. We gratefully acknowledge the inkind contribution of Roy T. Patterson and Jean. L. Patterson who provided field logistical support.

\section{Declaration of interest}

We wish to confirm that there are no known conflicts of interest associated with this publication and there has been no significant financial support for this work that could have influenced its outcome. 


\section{Introduction}

Arcellinida, also known as testate lobose amoebae (Mitchell et al., 2008), or as thecamoebians (Patterson and Kumar, 2002), are a group of shelled benthic protozoans that inhabit most terrestrial freshwater aquatic environments (Medioli and Scott, 1988; Patterson and Kumar 2002). The geographical distribution of Arcellinida is wide, extending from the tropics (Dalby et al., 2000; Farooqui and Gaur, 2007; Patterson et al., 2015) to the Arctic region (Collins et al., 1990; Beyens and Chardez, 1995; Patterson et al., 2015). Within this extensive geographical range the group is primarily found in freshwater lakes, rivers, and ponds (Patterson and Kumar, 2002; Neville et al., 2010; Schwind et al., 2015; Vázquez-Riveiros et al., 2007) and, to a lesser extent, brackish water habitats (Patterson et al., 1985; Charman et al., 2000). Arcellinida are distinguished by a test (shell) ranging in size from 5 to $500 \mu \mathrm{m}$ and are either autogenous (i.e. secreted by the organism) or xenogenous (i.e. constructed by the process of agglutinating materials like sand grains and diatom frustules), with the latter being of greater use in limnological and paleolimnological studies (Patterson and Kumar, 2002). While Arcellinida are most abundant in Holocene terrestrial aquatic deposits, their fossil record extends throughout the Phanerozoic (Foissner and Schiller, 2001; van Hengstum et al., 2007) and into the Late Neoproterozoic (Porter and Knoll, 2000)

The number of studies investigating the reliability of Arcellinida as proxy for variability in lacustrine environmental conditions has been steadily growing for the past few decades (e.g., Patterson et al., 1985, Asioli et al., 1996; Reinhardt et al., 1998; Neville et al., 2010; Patterson et al., 2013; Steele et al., 2018; Gavel et al., 2018). This increased interest in Arcellinida is attributed to: 1) their abundance in lacustrine substrates (500-3000 tests/ml; Patterson and Kumar, 2002); 2) their rapid reproduction rates (few days to a week); 3) the durability of their tests, which enhances their preservation potential; 4) the relative ease of taxonomic identification compared to other lacustrine microfaunal groups (e.g. diatoms); and, 5) their sensitivity to a wide range of environmental parameters. These attributes make Arcellinida an ideal tool for monitoring environmental change, human-made or otherwise, in lakes. Recent arcellinidan studies have focused on quantifying the relationship between Arcellinida community (i.e. assemblages) dynamics and variations in many physicochemical parameters, like lake acidity (Kumar and Patterson, 2000), pH variability (Patterson et al., 2013), nutrient loading (Patterson et al., 2012), water quality (Roe et al., 2010), land-use changes (Patterson et al., 2002), road salt contamination (Roe \& Patterson, 2014) and metal mining contamination (e.g., Asioli et al., 1996; Kihlman and Kauppila, 2009; Nasser et al., 2016). Most of these studies focused on assessing the response of the group to contemporary (i.e. spatial) or the long-term temporal impact of environmental variability. While the body of literature on lacustrine Arcellinida continues to grow, a gap remains in our understanding of the relationships between the dynamics of Arcellinida assemblages and short-term environmental trends in lakes.

The structure of microfaunal communities is in a state of constant change, mainly due to the influences of variations in biotic and abiotic factors in the environment (Brown et al., 2001). Environmental variability can occur over short- (seasonal and annual) to longer-time scales (subdecadal to thousands of years). Identifying the response of a microfaunal community (e.g. Arcellinida) to short-time scale changes is particularly imperative for accurately determining: 1) environmental preferences of certain taxa; 2) species and assemblage distributional patterns in 
different lake ecosystems; and, 3) primary drivers of variability in community structure (Levin, 1992; Thrush et al., 1997). While the sensitivity of testate amoebae assemblages to annual environmental changes has been frequently assessed in mediums like soil (Smith, 1973; Coûteaux, 1976; Laminger et al., 1980; Lousier, 1984), peatlands (Mazei and Tsyganov, 2007), rivers (Schwind et al., 2015) and ponds (Roe \& Patterson, 2006; Neville et al., 2010), similar assessments in lacustrine environments are currently limited (Laminger, 1971; Schönborn, 1992; Foissner, 1994; Kumar and Patterson, 2000; Farooqui et al., 2012; Davidova and Vasilev, 2013).

In this experiment, Arcellinida were examined from 22 surface sediment samples collected from comparable limnological environments (e.g. similar substrates and water depth) in eastern Canadian lakes Lac du Castor Blanc (SW Quebec) and Oromocto Lake (SW New Brunswick), to: 1) evaluate the consistency of the faunal compositions of Arcellinida assemblages found within the targeted homogenous environments; and, 2) assess the dynamics of arcellinidan assemblages in response to inter-annual limnological changes in samples collected from Oromocto Lake in $2010 \mathrm{CE}(n=10)$ and $2012 \mathrm{CE}(n=6)$. Results from this study provide new insight into the sensitivity of Arcellinida to short-term environmental changes, which is critical for confirming the reliability of utilizing the group as a tool for monitoring subtle trends of lacustrine environmental change.

\section{Study Area}

2.1 Lac du Castor Blanc

Lac du Castor Blanc $\left(46.145726^{\circ},-76.037677^{\circ}\right)$ is located in SW Quebec, approximately $90 \mathrm{~km}$ north of Ottawa in the Outaouais region (Figure 1B). The region is geologically part of the Grenville Super group characterised by Archean or Early Proterozoic metamorphic rocks hosting stratified zinc and iron deposits (Brown, 1982; Gauthier and Brown, 1986). The study area receives an average of $939.9 \mathrm{~mm}$ precipitation annually and is characterized by an annual temperature of $4.7^{\circ} \mathrm{C}$ (Environment Canada, 2018a). Areas of tall, high-density evergreens fringe the perimeter of the lake, with lower-density patches deciduous trees occurring further away from the lake shore.

Lac du Castor Blanc is relatively small in size (Area $=152.2 \mathrm{ha})$ and has an elongated and relatively meandering morphology stretching for $3.7 \mathrm{~km}$ in the north-south direction (Figure 1B). The lake is situated $174 \mathrm{~m}$ above sea level, with a river from Lac à Webb draining into its northern basin. Bathymetric information for the lake is currently limited and is exclusive to the central western basin, informally referred to as Gracefield Camp Cove below, which is characterizing by a water depth ranging from $1.5 \mathrm{~m}$ to a maximum depth of $10.5 \mathrm{~m}$ (Supplementary Table 1). Human development of the area began in $1840 \mathrm{CE}$ when Irish settlers formed a settlement called Gracefield south of the lake (Commission de toponymie, Quebec, 2015). A mica mine opened in $1896 \mathrm{CE}$ and was in operation until the $1908 \mathrm{CE}$ (Sabina, 1970). The lake has many cottages along the southern shoreline, as well as the large Gracefield Christian Camp and Retreat Centre, adjacent to Gracefield Camp Cove. 


\subsection{Oromocto Lake}

Oromocto Lake $\left(45.642225^{\circ},-66.997384^{\circ}\right)$ is found in SW New Brunswick, in Tweedside, a rural region within the greater Harvey area (Figure 1C). The lake is situated in the Saint John River Valley/Highland Foothills (Pronk and Allard, 2003). This region has been significantly modified by glacial and melt-water processes and is characterized by moderate relief and sand and gravel deposits forming eskers, kames and outwash deltas (Pronk \& Allard, 2003). Oromocto Lake is at an elevation of $20.7 \mathrm{~m}$ above mean sea level. The only sizeable lake inlet is Dead Brook, a small stream that drains into Wightman Cove at the north end of the lake. The average precipitation for the study area is $1077 \mathrm{~mm} /$ year, and an average annual temperature is $5.6^{\circ} \mathrm{C}$ (Environment Canada, 2018b). The vegetation cover around the lake consists of coniferous, broadleaf and mixed wood trees (Hanson, 2014).

Oromocto Lake is elongated and widens gradually toward the southern end (Figure 1C). The northeastern section of the lake forms an arm that protrudes and tapers eastward. There are two main basins in the open water area, a small northern sub-basin (water depth $=8.9 \mathrm{~m})$, and a bigger and deeper $(13.5 \mathrm{~m})$ southern basin (Hanson, 2014). Samples collected for this study were from Wightman Cove, which is flat-bottomed and draped by soft sediment in water depths varying from 2-5 m (Steele et al., 2018). There are a large number of cottages and yearround homes found within Wightman Cove and elsewhere along the western margin of the lake.

\section{Materials and Methods}

\subsection{Sampling Design and Field Work}

Sixteen surface-sediment samples were collected from stations in Wightman Cove, Oromocto Lake over two field seasons in $2010 \mathrm{CE}(n=10)$ and $2012 \mathrm{CE}(n=6)$ to determine if arcellinidan assemblages varied in response to subtle inter-annual changes in environmental conditions (Figure 1C). Substrates characterized by relatively uniform environmental conditions (e.g. similar water depth and sedimentary composition) were sampled as they are often represented by arcellinidan assemblages with a relatively consistent faunal structure (Steele et al., 2018). This was a critical component of this experiment as relative homogeneity within both limnological conditions and the associated arcellinidan assemblage structure is required to ensure that any identified changes in Arcellinida assemblage dynamics can be attributed to short-term environmental variability rather than differences in the sampled environment (e.g. littoral vs. open water environments). Following the same site selection criteria used for Oromocto Lake, six surface-sediment samples were collected from the limnologically similar Gracefield Camp Cove of Lac du Castor Blanc, Quebec in $2010 \mathrm{CE}$ as an outgroup against which to assess the homogeneity and consistency of arcellinidan assemblages found in Oromocto Lake. 


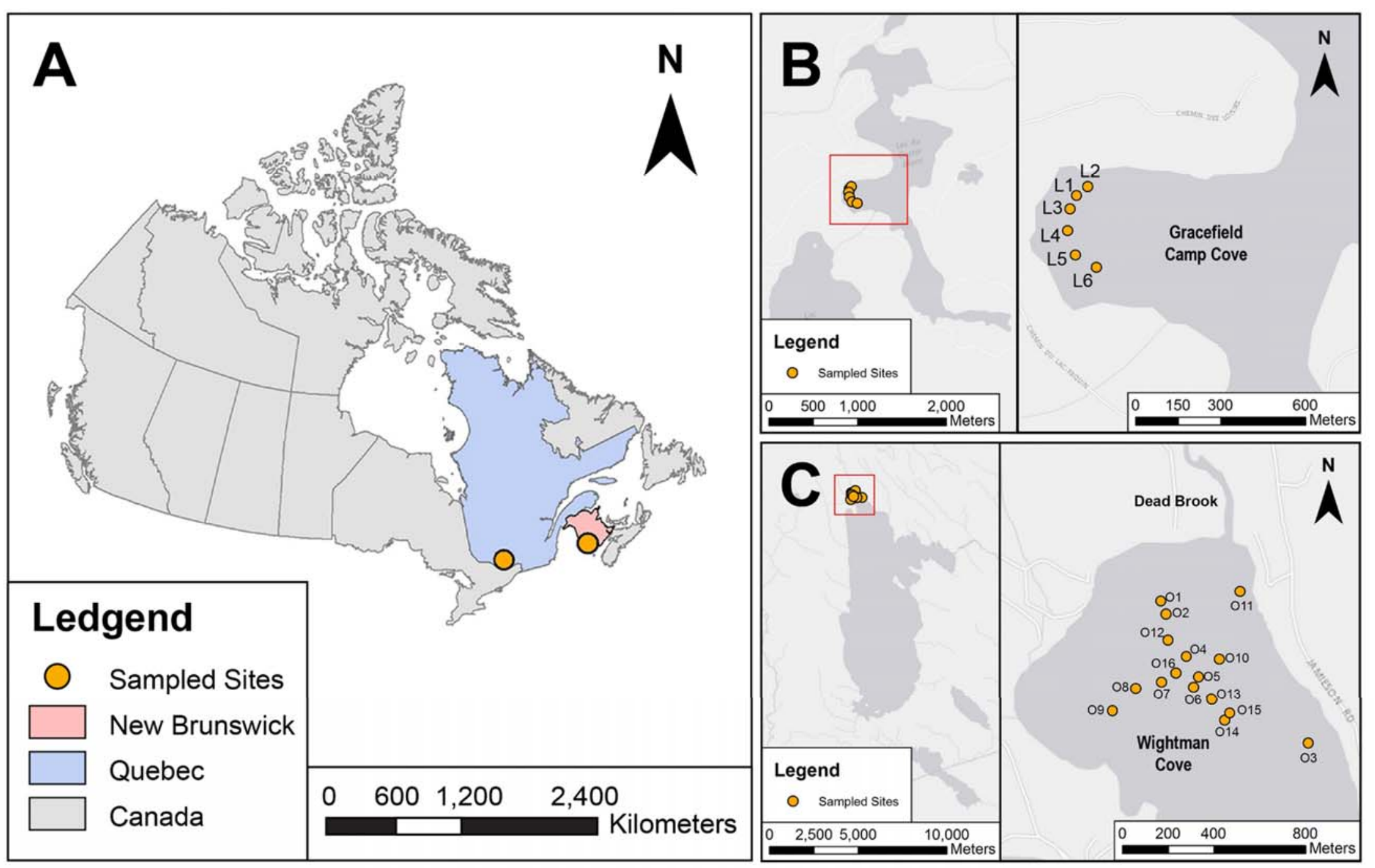

Figure 1. Map of the study areas. A) map of Canada showing the sampled lakes (yellow circles) in Quebec (light blue highlight) and New Brunswick (Light red highlight). B) A map showing the sampled sites (yellow circles) in Gracefield Camp Cove (red square), Lac du Castor Blanc, Quebec, Canada. C) A map showing the sampled sites (yellow circles) in Wightman Cove (red square), Oromocto Lake, New Brunswick, Canada. 
Sample sites were selected using a Lowrance Elit-4x fish finder (depth uncertainty $= \pm 0.6 \mathrm{~m}$ ) equipped with a bottom hardness indicator, which allowed for identification of muddy substrates where higher proportions of Arcellinida often dwell (Patterson and Kumar, 2002). The geographical locations of sampled sites in both lakes were determined using a Garmin GPSMPA 76Cx GPS unit (Supplementary Table 1). Water column environmental parameters data (e.g., dissolved oxygen [DO], pH, conductivity, and water temperature) were recorded in each lake basin, in the deepest sites, at $1 \mathrm{~m}$ intervals using a YSI Multi-parameter instrument equipped with quatro cables (Supplementary Table 1). Both lakes were accessible by road and samples were collected from a small boat using a standard Ekman grab sampler. The top $0.5 \mathrm{~cm}$ of sediment from each grab, where living arcellinidan populations are often found, was retained for analysis.

\subsection{Laboratory Analyses}

Geochemical, sedimentological and micropaleontological analyses were carried out on sub-samples. The geochemical composition of the material was determined using inductively coupled mass spectrometry (ICP-MS: 1F/AQ250 package) following aqua regia digestion at Bureau Veritas, Vancouver (Supplementary Table 1). Aqua regia digestion was chosen as this method captures the concentration of heavy metals and metalloids that can potentially be bioavailable (Nasser et al., 2016; Santoro et al., 2017).

Loss-on-ignition (LOI) analysis was carried out following Heiri et al. (2001) on sub-samples to estimate the percentage of organic, carbonate, and minerogenic content in the sediment (Supplementary Table 1). Wet sediment subsamples $(1 \mathrm{cc})$ were placed in weighed ceramic crucibles, which were subsequently placed in an oven overnight $\left(70 \mathrm{C}^{\circ}\right)$ to dry. A programmable Fisher Scientific Muffle furnace was then used for the sequential burning of the dried sub-samples at $500^{\circ} \mathrm{C}$ and $950^{\circ} \mathrm{C}$ in order to calculate the percentage of organic matter and carbonate content in each sample, respectively. Data generated by LOI can provide valuable information on sediment sources, surface processes such as erosion and lake productivity (Huang et al., 2004).

Subsamples were prepared for particle size analysis (PSA) by digesting sub-samples in a heated bath (70 $\mathrm{C}^{\circ}$ ) with $10 \% \mathrm{HCl}$ and $30 \% \mathrm{H}_{2} \mathrm{O}_{2}$ to remove carbonate and organic content, respectively (Murray, 2002; van Hengstum et al., 2007). Following digestion, sedimentary grain size in each sub-sample was analyzed using a Beckman Coulter LS13 320 laser diffraction analyzer fitted with a universal liquid medium (ULM) sample chamber over a measurement range between 0.4 and $20001 \mathrm{~m}$. Samples were loaded into the instrument until an obscuration level of $10 \pm 3 \%$ was attained. GRADISTAT (Version 8) (Blott and Pye, 2001) was used to compile the results (Supplementary Table 1). Garnet15 (mean diameter $15 \mu \mathrm{m}: \pm 2 \mu \mathrm{m}$ ), an accuracy standard supplied by Beckman Coulter, was run once per month. An in-house mud sample (Cushendun Mud; mean diameter $=20.5 \mu \mathrm{m}: \pm 0.76 \mu \mathrm{m}$ ) was run at the start of every session as a precision control.

Arcellinida analysis was carried out on all sub-samples. Five $\mathrm{cm}^{3}$ of wet sediments were sieved through $297 \mu \mathrm{m}$ and $37 \mu \mathrm{m}$ mesh to remove coarse and fine organic and mineral debris and retain arcellinidan tests. The samples were then split into six aliquots using a wet splitter (Scott and Hermelin, 1993) and examined wet in a gridded Petri Dish. Arcellinida species and strains in each sub-sample were identified and enumerated using an 
Olympus SZH dissecting binocular microscope at magnifications ranging between 20-50x until counts of a statistically significant number (at least 250 where possible) were obtained following Patterson and Fishbein (1989) (Supplementary Table 2). Arcellinida were identified using photomicrographs from the existing literature that utilize the 'strain' intrasubspecific taxonomic concept (Reinhardt et al. 1998; Roe et al., 2010; Patterson et al., 2012; Patterson et al., 2013; Nasser et al., 2016; Steele et al., 2018; Gavel et al., 2018) (Supplementary Table 2). Scanning electron microscope (SEM) images of common Arcellinida species and strains were obtained using a Tescan VegaII XMU VP SEM at Carleton University. All plates were digitally produced using Adobe Photoshop ${ }^{\mathrm{TM}}$ (CC6) (Figure 2, Figure 3).

\subsection{Statistical Analyses}

The probable error (pe) was calculated for each sample using the following formula:

$$
\text { pe }=1.96\left(\frac{s}{\sqrt{X_{i}}}\right)
$$

where $s$ is the standard deviation of the population count and $X_{i}$ is the number of counts (i.e. Arcellinida tests) at the station being investigated. A sample was deemed statistically insignificant if the probable error exceeded the total count for a sample (Patterson and Fishbein, 1989).

Standard error $\left(\mathrm{S}_{\mathrm{Xi}}\right)$ was calculated for each sample using the following equation:

$$
S_{X i}=1.96 \sqrt{\frac{F 1(1-F 1)}{N_{i}}}
$$

where $F 1$ is the fractional abundance of species and $\mathrm{Ni}$ is the total number of counts. Species were considered to be present in insignificant numbers if the standard error exceeded the total counts for that species in all the samples (Fishbein and Patterson 1993). Species with abundances higher than the standard error but are common only in a few samples were also removed as their inclusion would complicate the interpretation of ensuing statistical and multivariate analyses.

The Shannon Diversity Index (SDI; Shannon, 1948) was calculated in RStudio (version 0.98.1028) (R Core Team, 2014) to assess arcellinidan diversity as a measure of ecological health in both lakes. Samples were considered healthy if the SDI was between 2.5 and 3.5, in transition if SDI was between 1.5 and 2.5, and stressed if SDI was below 1.5 (Magurran, 1988; Patterson and Kumar, 2002). The ratio between centropyxid and difflugid species was calculated after the approach of Neville et al. (2010) and was used in tandem with SDI as a measure of the relative ecological health of the sampled lakes.

\subsubsection{Data screening and preparation}

To avoid any issues with running the multivariate statistical analysis, data sets used in this study (Arcellinida relative abundance, lake parameters, LOI, particle size and ICP-MS) went through a screening process, which removed any variables with $>25 \%$ of data values being: 1) insignificant and, or missing data values; and, 2) above or 
below instrumental detection limits. Any remaining values below the detection limit were converted to half the minimum detection limit, while any value above detection limit was converted to maximum detection limit (Reimann et al., 2008). 


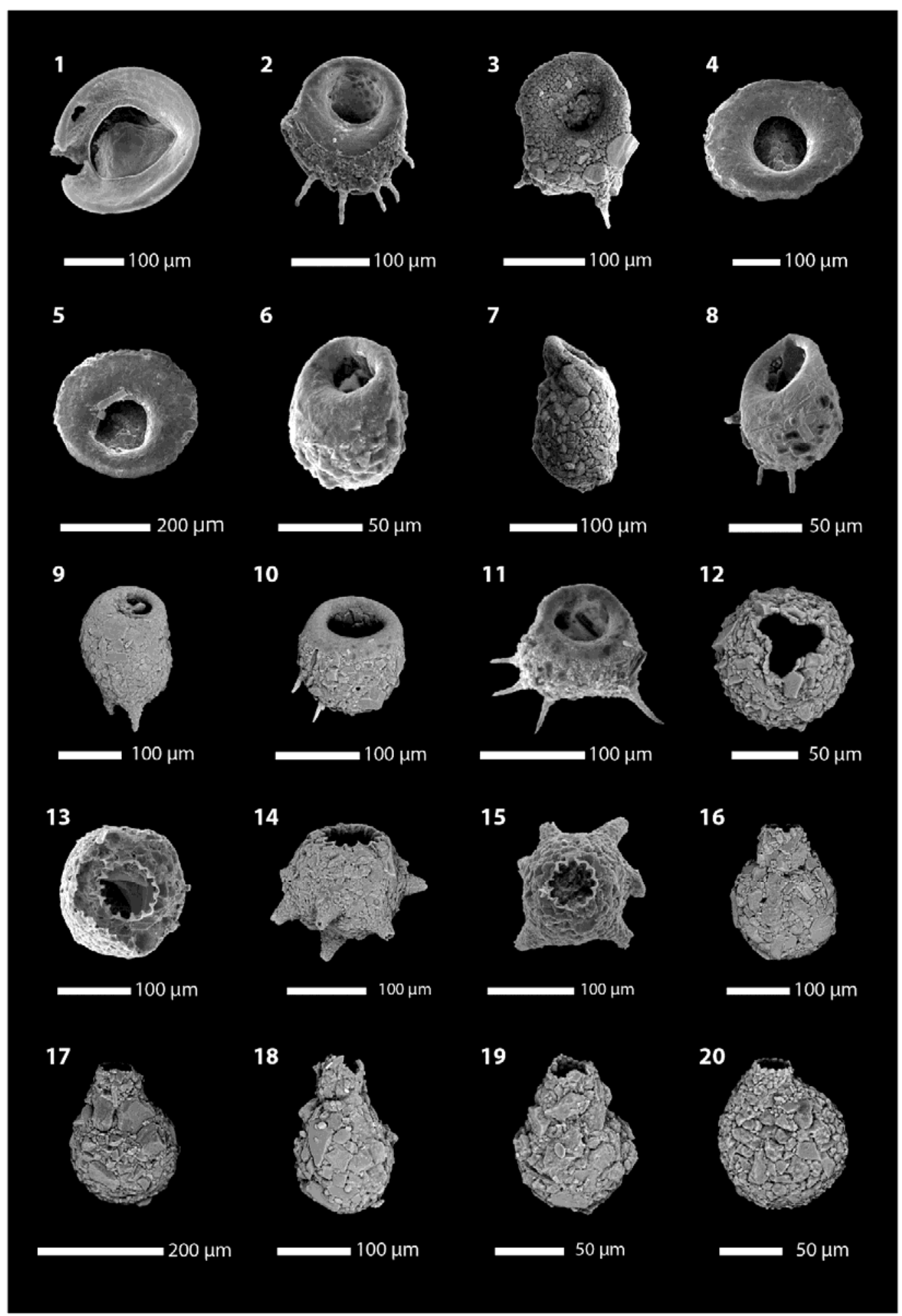


Figure 2: Arcellinina from Lac du Castor Blanc and Oromocto Lake. 1 Arcella vulgaris (Ehrenberg 1830). 2-3 Centropyxis aculeata (Ehrenberg 1832) stain “aculeata”. 4-5 Centropyxis aculeata (Ehrenberg 1832) stain “discoides". 6-7 Centropyxis constricta (Ehrenberg 1843) stain "aerophila”. 8-10 Centropyxis constricta (Ehrenberg 1843) stain “constricta”. 11 Centropyxis constricta (Ehrenberg 1843) stain "spinosa”. 12 Cucurbitella tricuspis (Carter 1856). 13-15 Mediolus corona (Wallich 1986). 16-17 Pontigulasia compressa (Carter 1864). 1819 Lagenodifflugia vas (Leidy 1874). 20 Lesquereusia spiralis (Ehrenberg 1840). 


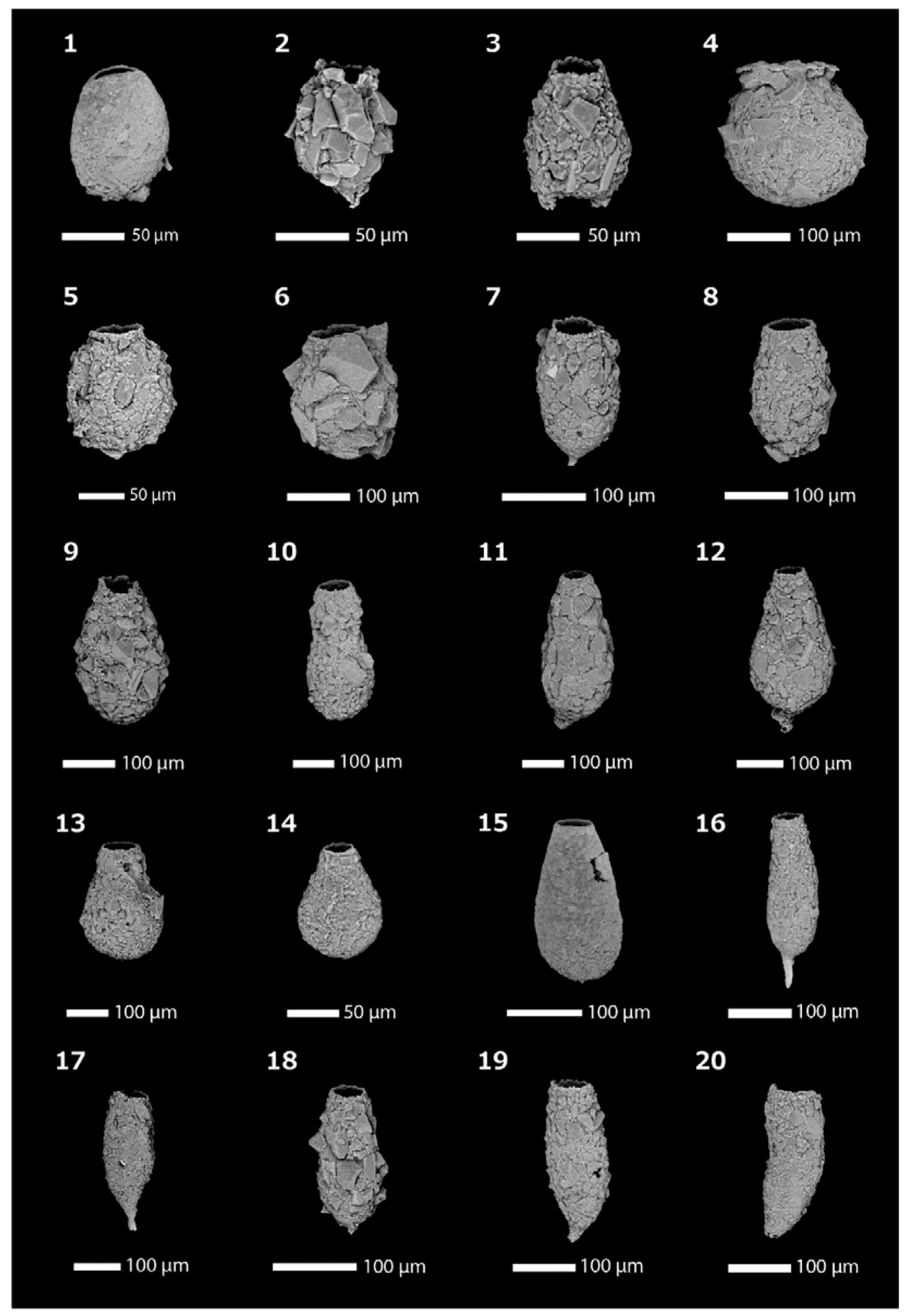


Figure 3: Arcellinina from Lac du Castor Blanc and Oromocto Lake.1 Heleopera sphagni (Leidy 1874). 2 Difflugia elegans (Penard 1890). 3 Difflugia bicornis (Penard, 1890). 4 Difflugia urceolata Carter 1864 strain "urceolata". 5 Difflugia urens (Patterson, MacKinnon, Scott, and Medioli 1985). 6 Difflugia glans (Penard 1902) strain "glans". 7 Difflugia glans (Penard 1902) strain “distenda”. 8 Difflugia glans (Penard 1902) strain "magna”. 9-10 Difflugia oblonga (Ehrenberg 1832) strain “oblonga”. 11-12 Difflugia oblonga (Ehrenberg 1832) strain "spinosa”. 13-14 Difflugia oblonga (Ehrenberg 1832) strain “tenuis". 15 Difflugia oblonga (Ehrenberg, 1832) strain "lanceolata”. 17 Difflugia protaeiformis (Lamarck 1816) strain "acuminata”. 18 Difflugia protaeiformis (Lamarck 1816) strain “claviformis". 19 Difflugia protaeiformis (Lamarck 1816) strain “curvicaulis". 20 Difflugia protaeiformis (Lamarck 1816) strain "sculpellum". 
The screening process resulted in the removal of ten measured parameters, all of which are from the ICP-MS dataset (omitted elements: boron [B], tungsten [W], Te [tellerium], Ge [germanium], Hf [Hafnium], Ta [tantalum], In [indium], Re [rhenium], Pd [palladium], and Pt [platinum])

A logarithmic transformation was performed on the dataset due to most of the parameters exhibiting a strong non-normal distribution (p-value $<0.005 ; n=39 / 55$ variables). A Hellinger transformation was used on the arcellinidan relative abundance data set as it is the recommended method of transformation when performing cluster analysis and ordination, especially linear methods like redundancy analysis, on species abundance data (Rao, 1995).

\subsubsection{Variables reduction}

A Principle Component Analysis (PCA; Pearson, 1901; Hotelling, 1933) plot was employed to evaluate redundancies in data to further reduce the number of parameters to be included in constrained ordination.

\subsubsection{Cluster analysis}

Q-mode and R-mode cluster analysis was carried out on the 33 arcellinidan species and strains in 22 samples determined to have statistically significant counts and not missing any values in the environmental data set. Q-mode cluster analysis was used to group samples according to similarities in their faunal structure using Ward's Minimum variance method (Ward, 1963; Fishbein \& Patterson, 1993), which is recorded as squared-Euclidean distances. Rmode cluster analysis was used to determine which species and strains $(n=33)$ are most closely associated with each other and to determine the faunal composition of the identified Arcellinida assemblages. The statistical significance of the identified clusters was calculated using the PVClust package in RStudio statistical software (version 0.98.1028) (R Core Team, 2014). A two-way cluster analysis heatmap was generated using the cim function of the mixOmics package in RStudio.

\subsubsection{Detrended Correspondence Analysis (DCA)}

Detrended Correspondence Analysis (DCA; Hill, 1979) was used to determine the axil length, necessary for selecting the proper constrained ordination method (e.g. redundancy analysis vs. canonical correspondence analysis), and to compare similarities between identified Arcellinida assemblages in a multidimensional space. The results of DCA revealed that the gradient length of the species data is $<2$, which indicate that redundancy analysis is the appropriate ordination analysis for this data set.

\subsubsection{Redundancy analysis (RDA)}

Redundancy analysis (RDA; van den Wollenberg, 1997) was used on the 22 samples and 33 statistically significant species 
and strains to assess and quantify the relationship between Arcellinida assemblages and the reduced measured variables. Redundancy analysis provided insight for interpreting the cluster analysis and the DCA results as it determines possible drivers of the variance in the arcellinidan distribution. Moreover, partial RDA coupled with variance partition provided an additional qualification of the proportion of the variance in the Arcellinida data set that can be attributed to the measured parameters. Variables with a $p$-value $<0.05$ were deemed to significantly contribute to the variance in the Arcellinida assemblages.

\subsubsection{Bray-Curtis Dissimilarity Matrix (BCDM)}

Bray-Curtis Dissimilarity Matrix (BCDM; Bray and Curtis, 1957) was performed on both the arcellinidan relative abundance and physicochemical parameters data sets to assess the faunal homogeneity of the identified assemblages by determining the level of dissimilarity between samples representing each assemblage. Additionally, BCDM was also used to confirm whether environmental conditions and arcellinidan assemblages differed between 2010 and 2012 in Oromocto Lake (Supplementary Table 3).

\section{Results}

\subsection{Lake Parameters}

Samples obtained from Gracefield Camp Cove in Lac du Castor Blanc are mostly from relatively shallow water depth (1.5-3.5 m; Supplementary Table 1). The lake has a median surface water $\mathrm{pH}$ and conductivity of 8.8 and $165 \mu \mathrm{m} / \mathrm{S}$, respectively (Supplementary Table 1). Water temperature measurements recorded in deeper water (10.5 $\mathrm{m}$ ) indicate that thermal stratification develops during the summer months with a thermocline at $8.5 \mathrm{~m}$ water depth (Supplementary Table 4). However, the stratification must only be fully developed for a short time each year as the lake bottom waters were well oxygenated (DO levels $=12.07 \mu \mathrm{m} / \mathrm{l}$; Supplementary Table 4).

As in the case of Gracefield Camp Cove, Lac du Castor Blanc, the bathymetry within Wightman Cove in Oromocto Lake is relatively shallow (2-5 m), with the exception of sample O16, which was collected from a water depth of $7 \mathrm{~m}$ (Supplementary Table 1). The surface of the lake is characterized by notably lower pH (7.44) and conductivity $(21.1 \mu \mathrm{m} / \mathrm{S})$ compared to levels recorded at Lac du Castor Blanc (Supplementary Table 1). The prevailing W-SW wind direction and large fetch across Oromocto Lake results in the lake being unstratified with respect to dissolved oxygen $($ surface $=2.4 \mu \mathrm{m} / 1$, bottom $=2.2 \mu \mathrm{m} / \mathrm{l})$ and water temperature $\left(\right.$ surface $=25^{\circ} \mathrm{C}$, bottom $=$ $24^{\circ} \mathrm{C}$; Supplementary Table 4).

\subsection{Textural and organic matter characteristics}

Textural and organic matter characteristics of study samples are listed in Supplementary Table 1. Samples from Lac $\mathrm{du}$ Castor Blanc are characterized by relatively low levels of organic matter (median $=2.7 \% ; n=6$ ), carbonates 
$($ median $=1.6 \% ; n=6)$ and minerogenic content $($ median $=3 \% ; n=6)$. The proportions of organic matter present at Oromocto Lake were similarly low (median $=2.4 \% ; n=16$ ) and were further characterized by lower carbonate $($ median $=0.3 \% ; n=16)$ and higher minerogenic content (median $=19.2 \% ; n=16)$ compared to Lac du Castor Blanc. Sediments from the sampled coves in both lakes are dominated by silt (Lac du Castor Blanc median $=79.2 \%, n=6$; and, Oromocto Lake median $=59.1 \% ; n=16$ ) with Oromocto Lake sediments having notably more sand (median sand $\%=32.9 \%, n=16$; Lac du Castor Blanc median sand $=13.2 \% ; n=6$ ).

\subsection{Identified Arcellinida Assemblages and Primary Controls}

Thirty-four arcellinidan species and strains were identified in twenty-two samples. All samples were found to have statistically significant arcellinidan counts and none were removed from statistical analysis. Out of 34 identified species and strains, 33 occurred in statistically significant numbers with only one taxon, Heleopera sphagni (Leidy 1874), yielding statistically insignificant number of tests.

Interpretation of the two-way cluster analysis "heatmap" revealed two distinct assemblages: 1) Lac du Castor Blanc Assemblage (LCA) (statistical significance $=99 \%[>2 \delta] ; n=6$ ); 2 ) Oromocto Lake Assemblage $($ OLA) (statistical significance $=94 \%[>2 \delta] ; n=16$ ), which was further divided into the Oromocto Lake 2010 Sub-Assemblage (OL10; statistical significance $=92 \%[>2 \delta] ; n=10)$, and Oromocto Lake 2012 Sub-assemblage $(\mathrm{OL} 12$; statistical significance $=90 \%[>2 \delta] ; n=6)$ as shown in Figure 4. The two-way cluster analysis heatmap, however, revealed five outliers that were exclusive to OLA (O4, O5, O6, O7, and O11) (Figure 4). Samples O4, O6 and $\mathrm{O} 7$ were collected during the 2010 field season but clustered separately from the remaining 2010 sample at a high level of statistical confidence $(91 \%[>2 \delta])$. The faunal composition of the three samples, however, were highly similar to that of the samples definitively comprising OL10, differing only in the proportions of minor arcellinidan taxa (relative abundance $<1.2 \%$ ). Therefore, the three samples were considered to be part of the OL10 sub-assemblage in this study. Sample O5 grouped with the samples collected during the 2012 samples, even though it was collected in 2010, while sample O11 that grouped most closely to the OL10 samples despite being collected in 2012 (Figure 4). The presence of some overlap between the sub-assemblages would be expected given the temporal and spatial nature of the study.

Results of the DCA revealed arcellinidan assemblages similar to those identified using Q- and R-mode cluster analysis (Figure 5). The DCA bi-plot also revealed a notable overlap between the samples of OL10 and OL12, particularly with samples O2, O3, and O5 plotting closely to the OL12 sub-assemblage (Figure 5).

Redundancy Analysis results were consistent with both cluster analysis and DCA in that the same assemblages and sub-assemblages were observed in the RDA tri-plot (Figure 6A). Redundancy analysis showed that axis 1 explained most of the variance in the Arcellinida assemblages $(60 \%$; $<0.001)$. Along with PCA, RDA facilitated the reduction of the number of parameters to be included, by identifying four measured variables that collectively explain a major proportion of the variance in the identified assemblages $(65.6 \%$; Figure $6 \mathrm{~B})$. Of the four variables, 


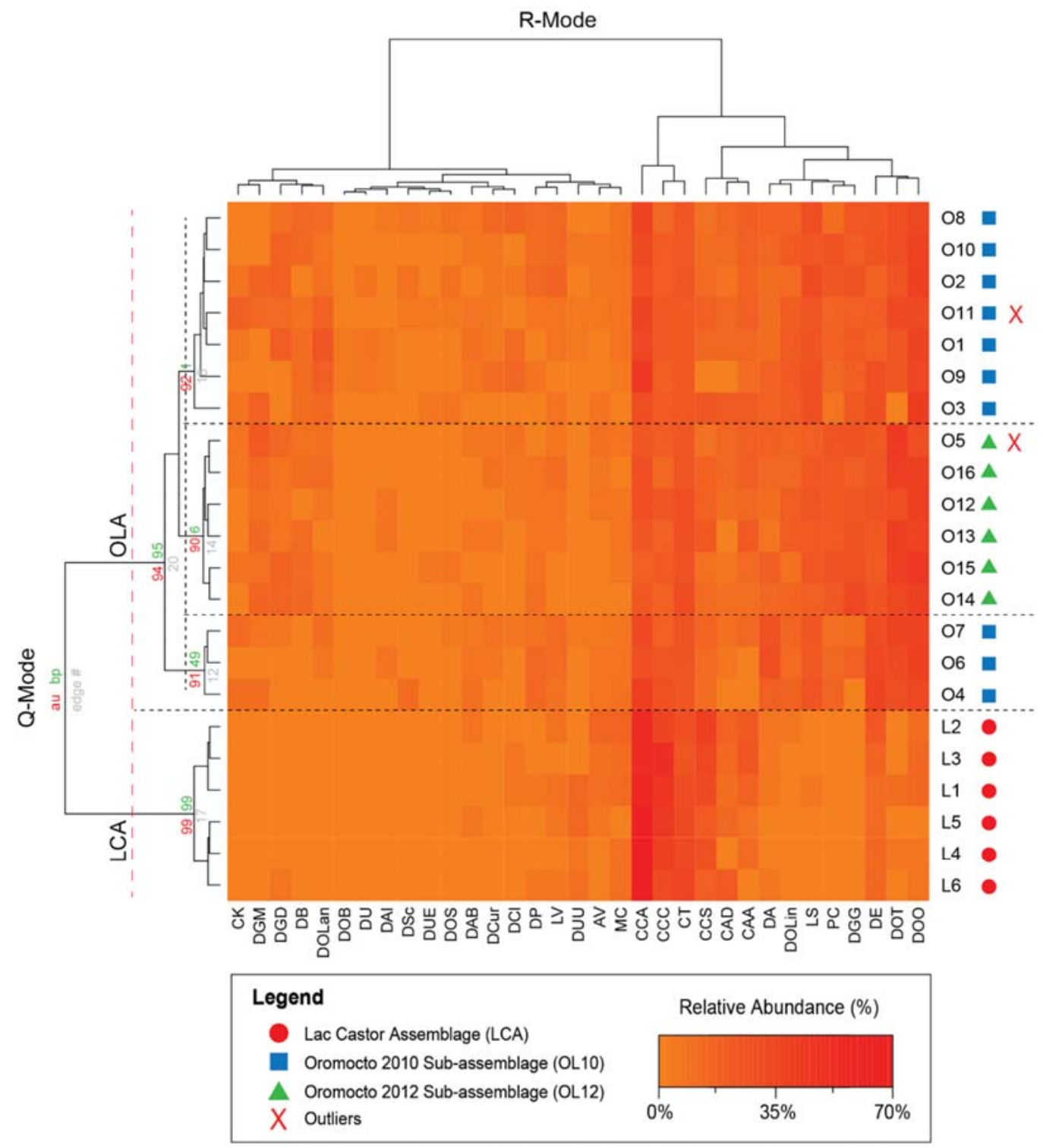

Figure 4. Combined Q-mode and R-mode cluster heatmap for the 22 samples and 33 statistically significant species and strains. Two faunal assemblages, and two sub-assemblages, are indicated. The colored squares (gradient of red) reflect the relative abundances of the Arcellinida species and strains. The statistical significance of the identified assemblages, as determined by using PVClust values, is displayed next to the assemblages (red number). $\mathbf{A V}=$ Arcella vulgaris; CAA = Centropyxis aculeata " aculeata", $\mathbf{C A D}=$ Centropyxis aculeata "discoides", $\mathbf{C C A}=$ Centropyxis constricta "aerophila", $\mathbf{C C C}=$ Centropyxis constricta "constricta", $\mathbf{C C S}=$ Centropyxis constricta "spinosa", $\mathbf{C T}=$ Cucurbitella tricuspis, $\mathbf{C K}=$ Cyclopyxis kahli, $\mathbf{D B}=$ Difflugia bidens, $\mathbf{M C}=$ Mediolus corona, $\mathbf{D G G}=$ Difflugia glans "glans", DGM = Difflugia glans "magna", DGD = Difflugia glans "distenda" , DOB = Difflugia oblonga "bryophila", DOL = Difflugia oblonga "lanceolata", DOL = Difflugia oblonga "linearis", DOO = Difflugia oblonga “oblonga", DOS = Difflugia oblonga "spinosa", DOT = Difflugia oblonga "tenuis", DP = Difflugia protaeiformis, 
DA = Difflugia acuminata, $\mathbf{D C L}=$ Difflugia claviformis; $\mathbf{D C U R}=$ Difflugia curvicaulis; $\mathbf{D S C}=$ Difflugia scalpellum; DAI = Difflugia acuminate "immanata; DAB = Difflugia acuminate "bicornis", DUU = Difflugia urceolata "urceolata", DUE = Difflugia urceolata "elongata", DU = Difflugia urens, $\mathbf{D E}=$ Difflugia elegans, $\mathbf{L V}=$ Lagenodifflugia vas, $\mathbf{L S}=$ Lesquereusia spiralis, $\mathbf{P C}=$ Pontigulasia compressa. 


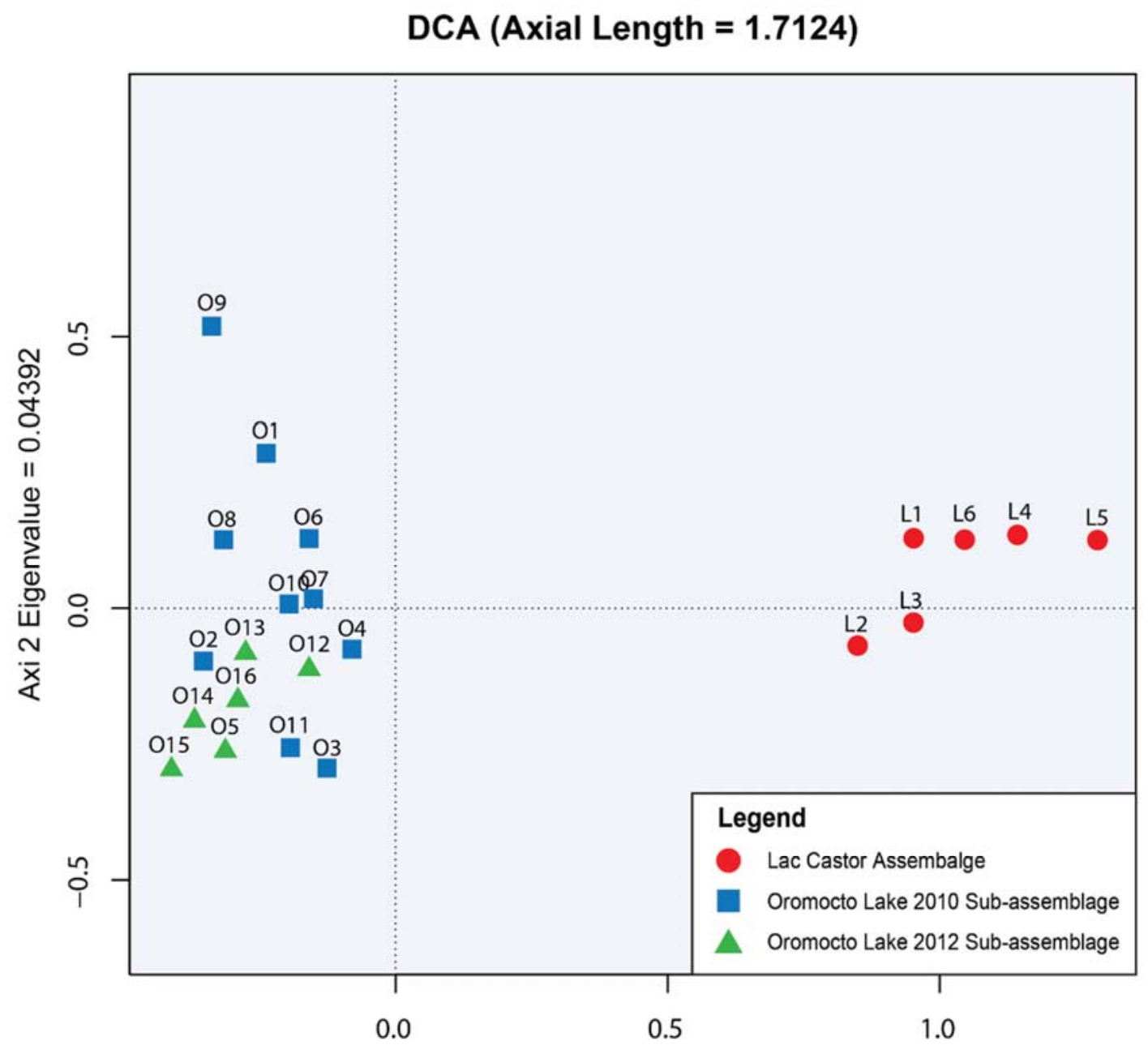

Axi 1 Eigenvalue $=0.2130$

Figure 5: Detrended correspondence analysis (DCA) showing the results for the two Arcellinida assemblages and two sub-assemblages in multidimensional space. 


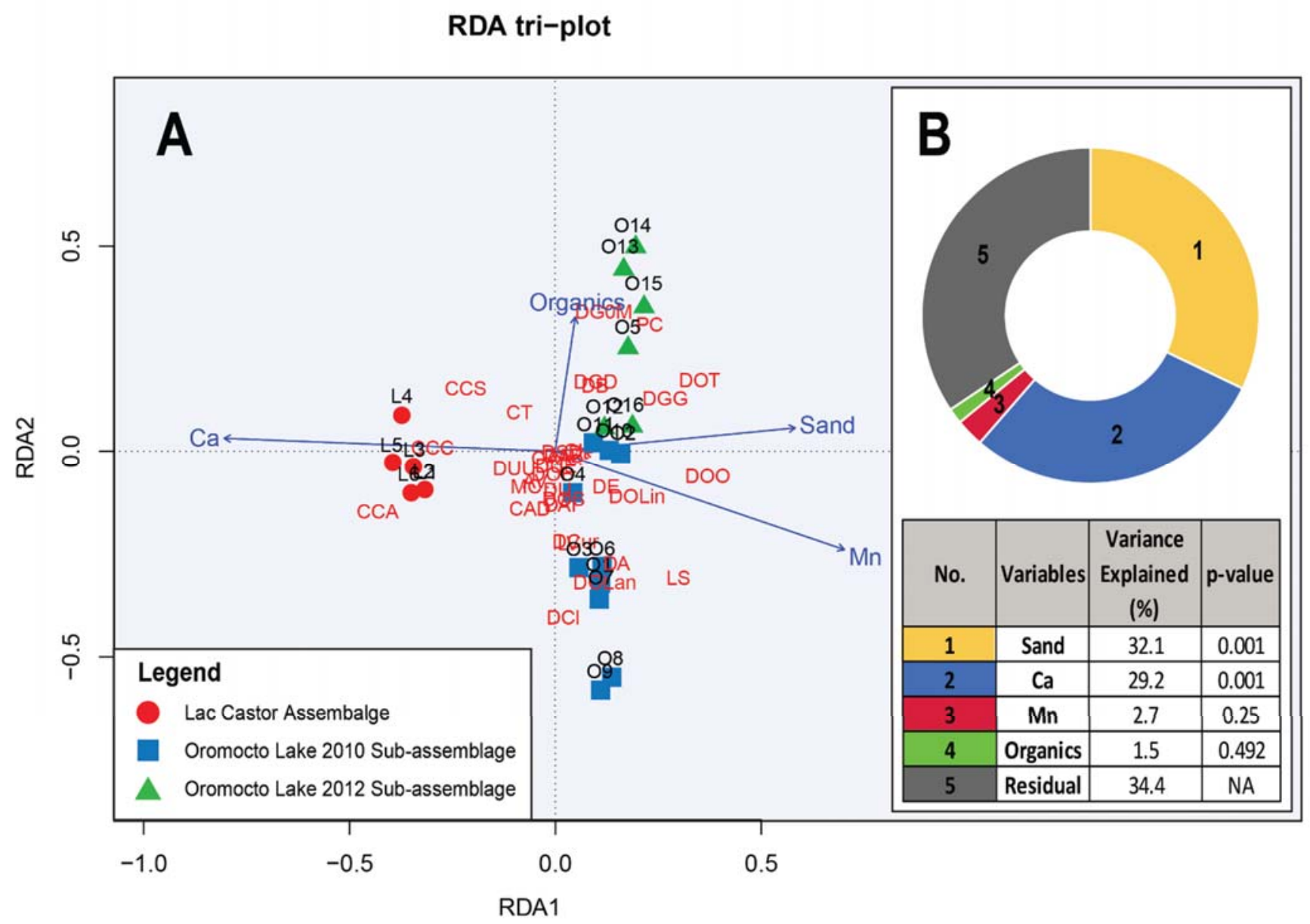

Figure 6: (A) Redundancy Analysis (RDA) species-environment-sample tri-plot for the 22 surface-sediment samples that yielded statistically significant proportions of 33 Arcellinida taxa. The tri-plot also shows the assemblages and sub-assemblages and their relationship with the measured variables. (B) Partial Redundancy Analysis (pRDA) with variance partitioning test showing the percentage variance in the Arcellinida data set that is explained by the measured variables.

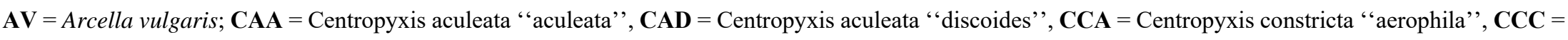


Centropyxis constricta "constricta", $\mathbf{C C S}=$ Centropyxis constricta "spinosa", $\mathbf{C T}=$ Cucurbitella tricuspis, $\mathbf{C K}=$ Cyclopyxis kahli, DB = Difflugia bidens, MC = Mediolus corona, $\mathbf{D G G}$ = Difflugia glans "glans", DGM = Difflugia glans "magna", DGD = Difflugia glans "distenda", DOB = Difflugia oblonga "bryophila", $\mathbf{D O L}=$ Difflugia oblonga "lanceolata", DOL = Difflugia oblonga "linearis", $\mathbf{D O O}=$ Difflugia oblonga "oblonga", DOS = Difflugia oblonga "spinosa", $\mathbf{D O T}=$ Difflugia oblonga "tenuis", DP = Difflugia protaeiformis, DA = Difflugia acuminata, $\mathbf{D C L}=$ Difflugia claviformis; $\mathbf{D C U R}=$ Difflugia curvicaulis; $\mathbf{D S C}=$ Difflugia scalpellum; DAI = Difflugia acuminate "immanata; $\mathbf{D A B}=$ Difflugia acuminate "bicornis", DUU = Difflugia urceolata "urceolata", DUE = Difflugia urceolata "elongata", $\mathbf{D U}=$ Difflugia urens, $\mathbf{D E}=$ Difflugia elegans, $\mathbf{L V}=$ Lagenodifflugia vas, $\mathbf{L S}=$ Lesquereusia spiralis, $\mathbf{P C}=$ Pontigulasia compressa. 
sand particle size (32.1\%) and calcium (Ca) (29.2\%) explained the majority of the total variance $(61.3 \%$; $p$ value $=0.001)$. In comparison, manganese $(\mathrm{Mn})(2.7 \%)$ and organic content $(1.5 \%)$ are less significant $(p$-value $>0.001$ ), explaining a notably lower portion of the total variance (4.3\%) (Figure $6 \mathrm{~B})$.

\subsection{Description of Identified Arcellinida Assemblages}

\subsubsection{Lac du Castor Blanc Assemblage 'LCA' $(n=6)$}

The faunal structure of the Lac du Castor Blanc Assemblage (LCA) was dominated by Centropyxis constricta (Ehrenberg 1843) strain "aerophila" (median relative abundance $=44.8 \%$ ), C. constricta (Ehrenberg 1843) strain "constricta" (median relative abundance $=19.7 \%$ ), and C. constricta (Ehrenberg 1843) strain "spinosa" (median relative abundance $=10.2 \%$; Supplementary Table 5). Other centropyxids like C. aculeata (Ehrenberg 1832) strain "aculeata" (median relative abundance $=2.4 \%$ ) and C. aculeata (Ehrenberg 1832) strain "discoides" (median relative abundance $=2.3 \%$ ) were also present but in low proportions. The dominance of centropyxid species and strains was illustrated by low D/C ratios characterizing the samples of LCA (0.044-0.15; Supplementary Table 5). The assemblage was also characterized by notable number of Cucurbitella tricuspis (Carter 1832) (median relative abundance $=11.2 \%$ ). The measured SDI for samples comprising LCA (SDI range $=1.3-2)$ was reflective of low to moderate diversity and stressed to transitional environmental conditions (Supplementary Table 5). Samples comprising the LCA were collected close to shore in relatively shallow water depth (1.5-3.5m; Figure 1B). These samples were retrieved from silt-dominated (median silt $\%=79.2 \%$ ) substrates characterized by relatively low organic contents ranging between 2.2-2.9\% (Supplementary Table 5).

Q-mode cluster analysis and DCA results indicated that LCA was highly distinguishable from the Oromocto Lake assemblage (Figures 4, 5). The results of RDA tri-plot show that LCA correlates positively with Ca, and negatively with the sand particle fraction and Mn (Figure 6A).

\subsubsection{Oromocto Lake Assemblage 'OLA' $(n=16)$}

Unlike the LCA, the Arcellinidan composition of the Oromocto Lake assemblage (OLA) was dominated by Difflugia oblonga Ehrenberg 1832 strain “oblonga” (median relative abundance $=15.9 \%$ ), and D. oblonga Ehrenberg 1832 strain "tenuis" (median relative abundance $=11.2 \%$; Supplementary Table 5). Of the centropxiid species and strains, only C. constricta (Ehrenberg 1843) strain "aerophila" (median relative abundance $=10.3 \%$ ) was present in high proportions. Other common species included D. elegans (median relative abundance $=7 \%$ ), Lesquereusia spiralis (median relative abundance $=6.8 \%$ ), C. tricuspis (Carter 1832) (median relative abundance $=$ 6.5\%), D. glans (Penard 1902) strain "glans" (median relative abundance $=5.5 \%$; Supplementary Table 5). The assemblage was highly diverse $(\mathrm{SDI}=2.47-2.81)$ and had a high proportion of difflugids $(\mathrm{D} / \mathrm{C}$ ratio $=1.5-3.2$; Supplementary Table 5). Samples of the OLA were collected from substrates that were silt-dominated (median silt\% 
$=59 \%$ ) but contained higher proportions of sand (median sand $\%=32.9 \%$ ). Compared to Lac du Castor Blanc, Oromocto Lake sediments have slightly higher levels of organic content (1.9-3.99\%; Supplementary Table 5).

The DCA bi-plot showed samples comprising the OLA clustering distinctly from the LCA samples. While the OLA samples were grouped closely, their grouping was not as tight as that of the LCA samples (Figure 5). The RDA tri-plot showed that samples of OLA correlated positively with the sand size fraction, Mn, and organic content, and negatively with $\mathrm{Ca}$ (Figure 6A).

\subsubsection{Oromocto Lake 2010 Sub-Assemblage 'OL10’ ( $n=8)$}

The faunal composition of the Oromocto Lake 2010 sub-assemblage (OL10) was dominated by Difflugia oblonga Ehrenberg 1832 strain “oblonga" (median relative abundance $=15.6 \%$ ) and D. oblonga Ehrenberg 1832 strain "tenuis" (median relative abundance $=10 \%$; Supplementary Table 5). Other common species included C. tricuspis (Carter 1832) (median relative abundance $=6.4 \%)$, D. glans (Penard 1902) strain "glans" (median relative abundance $=4.5 \%$ ), and D. oblonga Ehrenberg 1832 strain "linearis" (median relative abundance $=3.8 \%$ ). Centropyxid taxa were present but in low proportions as only C. constricta (Ehrenberg 1843) strain "aerophila" (median relative abundance $=13.2 \%$ ) were present in notable numbers (Supplementary Table 2). This assemblage was diverse $(\mathrm{SDI}=2.47-2.81)$ and had a high proportion of difflugids $(\mathrm{D} / \mathrm{C}$ ratio=1.5-3.2). Samples of this assemblage were collected from silt-dominated substrates (median silt $\%=59 \%$ ) except for sample O2 that was collected from silty substrates with notably high percentage of sand (median sand $\%=59.1 \%$ ). Oromocto Lake sediments have slightly higher levels of organic content (1.9-2.8\%) and Mn (median Mn concentration = $1522 \mathrm{ppm}$ ) relative to the Lac du Castor Blanc material. (Supplementary Figure 5).

While samples comprising OL10 were seen grouping closely on the DCA plot, samples O2, O3, and O5 appeared to overlap with the Oromocto Lake 2012 sub-assemblage (Figure 5). Redundancy Analysis results revealed a positive association between OL10 samples and Mn, Sand particle size, and a negative one with Ca (Figure 6).

\subsubsection{Oromocto Lake 2012 Sub-Assemblage 'OL12’ ( $n=8)$}

Similar to what was observed in sub-assemblage OL10, the faunal composition of the Oromocto Lake 2012 subassemblage (OL12) was diverse with SDI measurements indicative of relatively healthy environmental conditions (SDI range $=2.53-2.81)$ and $\mathrm{D} / \mathrm{C}$ ratios reflective of the dominance of difflugiid taxa $(\mathrm{D} / \mathrm{C}$ ratio $=1.4-5.1)$. The samples of this sub-assemblage were dominated D. oblonga Ehrenberg 1832 strain “oblonga” (median relative abundance $=17 \%$ ), and D. oblonga Ehrenberg 1832 strain "tenuis" (median relative abundance $=17 \%$ ). Species like C. tricuspis (Carter 1832) (median relative abundance $=8.8 \%$ ), and D. glans (Penard 1902) strain "glans" (median relative abundance $=7.6 \%$ ) were also common members of the sub-assemblage. Members of the genus Centropyxis were present in sub-assemblage OL12 in low numbers. Samples comprising this sub-assemblage were acquired in the 2012 field season and were collected from water depths ranging from $2 \mathrm{~m}$ to $7 \mathrm{~m}$. Compared to subassemblage O10, samples comprising sub-assamblage OL12 were characterized by a small, yet notable, increase in 
organic content (2.2-3.9\%) and slightly lower Mn concentrations (median Mn concentration = 1177.5 ppm; (Supplementary Table 5).

The results of DCA were in agreement with the two-way cluster analysis heat map and showed samples of sub-assemblage OL12 loading tightly in multidimensional space (Figures 4, 5). Similar to what was observed with sub-assemblage OL10, the RDA plot showed that sub-assemblage OL12 correlating positively with organics and sand particle size, and negatively with the $\mathrm{Ca}$ (Figure 6).

\section{Discussion}

\subsection{Arcellinida assemblage homogeneity}

Cluster analysis revealed two distinct arcellinidan assemblages, with one assemblage found in Lac du Castor Blanc (LCA) and the other in Oromocto Lake (OLA). The significant difference in the faunal composition and diversity of both assemblages reflected the different limnological conditions in both lakes. The LCA reflects stressed to transitional environmental conditions in Lac du Castor Blanc, while the OLA is indicative of healthier conditions. More specifically, the low diversity LCA (SDI range $=1.3-2$ ) is dominated by opportunistic centropyxid species and strains (median D/C = 0.08) (Medioli and Scott, 1988; Patterson et al., 1996; Reinhardt et al., 1998). Conversely, the diverse OLA (SDI range $=2.4-2.8)$ is characterized by abundant difflugiid taxa and C. tricuspis $($ median $\mathrm{D} / \mathrm{C}=2.4)$, which are known to thrive in organic rich substrates and healthy environmental conditions (Collins et al., 1990).

While the arcellinidan structure of both assemblages differed significantly, the faunal composition of samples characterizing each assemblage were relatively homogenous. Cluster analysis and PVClust results provide support for this assessment and with samples comprising each assemblage grouping closely with a high degree of statistical significance $(\mathrm{LCA}=99 \%[>2 \delta] ;$ OLA $=94 \%[>2 \delta])$ (Figure 4). As expected, DCA and RAD plots revealed a notable separation between the LCA and OLA, as well as a close association of centropyxiids with the LCA and difflugiids with the OLA (Figure 5, 6A). The Bray-Curtis dissimilarity matrix provided further confirmation of the distinction between both assemblages and uniformity of their faunal composition (Supplementary Table 3). Samples comprising each assemblage had low dissimilarity $(<0.3)$ values, in terms of the measured parameters and arcellinidan assemblage composition, and higher dissimilarity values when the LCA and OLA were compared (>0.3) (Supplementary Table 3). These results supported the findings of Steele et al. (2018) who confirmed the uniformity of arcellinidan assemblages in closely spaced samples collected from relatively homogenous limnological environments.

\subsection{Controls over Arcellinida assemblage composition}

While the RDA analysis revealed four significant measured parameters that collectively explained $65.6 \%$ of the variance recognized in the arcellinidan distribution, a considerable portion of the variance was explained by two variables: sand size fraction (32.1\%) and $\mathrm{Ca}(29.2 \%$; Figure $6 \mathrm{~B})$. This result is expected as values for these 
parameters exhibited the highest variance amongst all the measured variables in both lakes (Supplementary Table 1). The sedimentary composition of lacustrine substrates has been shown to influence the faunal distribution of Arcellinida, with healthy and abundant assemblages often dwelling in silt- to mud-dominated substrates, while stress assemblages characterize sand-dominated substrates, where populations of bacteria and other prey in these generally higher energy environments are reduced (Dalby et al., 2000; Roe and Patterson, 2006; Steele et al., 2018). A major difference in the sedimentary composition between the basins examined was that sediment samples from Oromocto Lake had higher levels of sand (median sand $\%=32.9 \% ; n=16$ ) compared to the Lac du Castor Blanc samples (median sand $\%=13.2 \% ; n=6$; Supplementary Table 5). However, the sedimentary composition of the OLA was still dominated by the silt size fraction (median silt $\%=59.1 \% ; n=16$ ), which may account for the high faunal diversity in the OLA samples.

Calcium concentrations were particularly high in Lac du Castor Blanc (median $\mathrm{Ca}=212150 \mathrm{ppm} ; n=6$ ) and comparatively lower in Oromocto Lake (media $\mathrm{Ca}=2250$ ppm; $n=16$; Supplementary Table 5). The RDA plot reveals a strong association between the LCA, stress-indicating arcellinidan taxa (centropyxiids) and Ca along the first RDA axis (Figure 6A). High dissolved Ca concentrations in water can elevate $\mathrm{pH}$ levels, which may explain why the $\mathrm{pH}$ level of Lac du Castor Blanc (median $\mathrm{pH}=8.88$ ) is significantly higher than that of Oromocto Lake (median $\mathrm{pH}=7.35$ ). The variability of $\mathrm{pH}$ in lakes has been shown to impact the distribution of Arcellinida (Kumar and Patterson, 2000; Patterson and Kumar, 2002; Patterson et al., 2013). Therefore, the elevated pH in Lac du Castor Blanc may have contributed, along with other confounding variables, to stressing the more sensitive and specialized arcellinidan taxa (e.g. difflugiid species and C. tricuspis), thus providing a possible explanation for the relatively low $\mathrm{D} / \mathrm{C}$ ratios characterizing the LCA.

Compared to sand particle size and $\mathrm{Ca}$, the remaining contributing variables ( $\mathrm{Mn}$, and organic content) explain a significantly lower proportion of the total variance in the arcellinidan distribution. This reduced apparent contribution is attributed to the low variance in Mn concentrations and organic content across the dataset (Supplementary Table 1). Both variables, especially Mn, exhibited a relatively stronger influence on the distribution of Arcellinida in Oromocto Lake compared to Lac du Castor Blanc. Manganese is a redox-sensitive element that is common within the earth's crust and highly soluble in surface and ground waters (Delfino et al., 1968). The study area in Wightman Cove of Oromocto Lake is adjacent to an anticline along the western margin composed of fossiliferous Carboniferous sandstones and conglomerates. These rocks host Mn nodules (Robb, 1968), which dissolve and are carried by groundwater outflow through the many springs found along the western shore and within the lake. The Mn concentrations are higher toward the western side of the cove, suggesting that these springs are the most likely source of this assemblage control. While $\mathrm{Mn}$ is an essential micronutrient for lake biota (NAS, 1977; CWQG, 1987) it can be toxic when present in high concentrations (Fales and Ohki, 1982; Davies and Brinkman, 1994). As Canadian Interim Sediment Quality Guidelines (ISQG) are yet to be established for Mn, it cannot be used to assess whether levels of $\mathrm{Mn}$ in Oromocto Lake are high enough to have any adverse effects on the arcellinidan community. However, the high diversity of OLA (SDI = 2.4-2.8) reflects healthy environmental conditions, indicating that although Mn seems to influence the arcellinidan community in the lake, its impact is most likely not deleterious. 
5.3 Arcellinida assemblage dynamics in response to inter-annual environmental variability

In addition to the identification of two primary arcellinidan assemblages, one each in Oromocto Lake and Lac du Castor Blanc, the recognition of two distinct sub-assemblages in Oromocto Lake (OL10 and OL12 sub-assemblages collected through two sampling seasons in $2010 \mathrm{CE}$ and $2012 \mathrm{CE}$ respectively) warrants special attention. The difference between sub-assemblages was driven by changes in the relative abundance of $D$. oblonga "oblonga", and D. oblonga "tenuis" which underwent a small, yet notable, increase in relative abundance in sub-assemblage OL12 (median relative abundance $=17 \%$ and $17.1 \%$, respectively; $n=6$ ) compared to sub-assemblage O10 (median relative abundance $=15.6 \%$ and $10 \%$, respectively; $n=10$; Supplementary Table 5 ). There was also a concurrent decline in the proportion of centropyxiid species and strains in sub-assemblage OL12. Ecosystems with higher proportions of difflugiid species and strains have previously been correlated with organic-rich substrates and relatively healthy environmental conditions (Collins et al., 1990). The increase in the proportions of difflugids here is similarly attributed to a small but significant increase in the levels of organic content in Wightman Cove between $2010 \mathrm{CE}$ (median organic content $=2.4 \%$; range $=1.9-2.8 \%$ ) and $2012 \mathrm{CE}$ (median organic content $=2.8 \%$; range $=$ 2.2-3.9\%). These results are in agreement with the findings of Steele et al (2018), who reported a similar association between the increase of both organic content of sediments from Wightman Cove, which by $2016 \mathrm{CE}$ had increased significantly to a median organic content of $15.3 \%$, and the abundance of difflugiids taxa, particularly D. oblonga "oblonga" (median relative abundance $=22.8 \%$; range $=19-26 \%$ ). The results presented here provide clear evidence of the sensitivity and responsiveness of Arcellinida assemblages to inter-annual changes in environmental conditions, and elucidates the potential of using the group as a reliable tool for monitoring subtle temporal limnological variability in lakes.

\section{Conclusions}

In this experiment Arcellinida species and strains from 22 surface-sediment samples from similar limnological environments in the Gracefield Camp Cove, Lac du Castor Blanc and Wightman Cove, Oromocto Lake were used to: 1) evaluate the similarity of Arcellinida assemblages found in similar limnological environments; and 2) assess inter-annual arcellinidan assemblage dynamics that developed in response to subtle temporal changes in environmental conditions that in turn developed in the same area of Wightman cove between $2010 \mathrm{CE}(\mathrm{n}=10)$ and $2012 \mathrm{CE}(\mathrm{n}=6)$.

Statistical (cluster analysis and BCDM) and ordination analyses (DCA and RDA) were used to characterize the arcellinidan assemblages identified in each lake, and to quantify the response of individual taxa and assemblages to variations in sedimentary geochemistry, organic content, and relative abundance of mud, silt and sand. The Qand R-mode Cluster analysis and DCA revealed that despite broad limnological similarities, the two lakes hosted distinct arcellinidan assemblages, the LCA and OLA, characterized by a relatively homogenous faunal structure in each. RDA analysis revealed that assemblage composition was most significantly controlled by four physicochemical parameters, which explained $65.6 \%$ of the total variance: sand size fraction; $\mathrm{Ca} ; \mathrm{Mn}$; and organic 
content. The PVClust analysis supported by BCDM support the interpretation of distinct sub-assemblages OL10 and OL12 developed in the years $2010 \mathrm{CE}$ and $2012 \mathrm{CE}$ within the same region of Wightman Cove, Oromocto Lake. The OL12 sub-assemblage was characterized by higher proportions of the healthy-lake-indicating diffluggiid taxa. We hypothesize that a slight increase in lake productivity as indicated by an increase in organic content of sediments between $2010 \mathrm{CE}$ and $2012 \mathrm{CE}$ contributed to the arcellinidan assemblage change.

Results of this study demonstrate that there is a general homogeneity of assemblages found in lakes or contained sub-basins that are characterized by similar limnological conditions, which is of importance when designing sampling strategies for intra- and inter-lake research projects. The observation that subtle inter-annual changes in arcellinidan assemblage in Wightman Cove was recognizable provide confirmation that Arcellinida can be successfully deployed as a tool for monitoring limnological change at short-term time scales in lacustrine research. 


\section{References}

1. Asioli, A., Medioli, F.S., Patterson, R.T., 1996. Thecameobians as a tool for reconstruction of paleoenvironments in some Italian lakes in the foothills of the southern Alps (Orta, Varese and Canada). J. Foraminiferal Res. 26:248-263. https://doi.org/10.2113/gsjfr.26.3.248

2. Blott, S.J., Pye, K., 2001. GRADISTAT: A grain size distribution and statistics package for the analysis of unconsolidated sediments. Earth Surf. Process Landforms 26:1237-1248.

3. Bray, J.R., Curtis, J.T., 1957 An ordination of the upland forest communities of southern Wisconsin. Ecol. Monogr. 27:325-349. https://doi.org/10.2307/1942268

4. Brown, A.C., 1982. Grenville iron-formations and associated stratiform zinc mineralization, Roddick Lake area, Mount Laurier Basin, Quebec. Can. J. Earth Sci. 19(8):1670-1679. https://doi.org/10.1139/e82-142

5. Brown, J.H., Whitham, T.G., Morgan Ernest, S.K., Gehring, C.A., 2001. Complex species interactions and the dynamics of ecological systems: long-term experiments. Sci. 293:643-650.

6. Beyens, L.,Chardez, D., 1995. An annotated list of testate amoebae observed in the Arctic between the longitudes $27^{\circ} \mathrm{E}$ and $168^{\circ} \mathrm{W}$. Archiv für Protistenkunde 146, 219-233.

7. Canadian Water Quality Guidelines, 1987. Canadian Council of Ministers of Environment, wit periodic updates

8. Carter, H.J., 1856. Note on the freshwater Infusoria of the island of Bombay. Ann. Mag. Nat. Hist. 18(104): $115-132$. https://doi.org/10.1080/00222935608697625

9. Carter, H.J., 1864. On freshwater Rhizopoda of England and India. Ann. Mag. Nat. Hist. ser 3, 13:18-39

10. Charman, D.J., Hendon, D., Woodland, W.A., 2000. The identification of testate amoebae (Protozoa: Rhizopoda) in peats. Quaternary Res. Association, London, 147.

11. Collins, E.S., McCarthy, F.M., Medioli, F.S., Scott, D.B., Honig, C.A., 1990. Biogeographic distribution of modern thecamoebians in a transect along the eastern North American coast. In: Hemleben, C., Kaminski, M.A., Kuhnt, W., Scott, D.B. (Eds.), Paleoecology, Biostratigraphy, Paleoceanography and Taxonomy of Agglutinated Foraminifera. NATOAdvanced Study Institute Series, Series C, Mathematical and Physical Sciences 327:783-791

12. Commission de toponymie, Quebec., 2015. Gracefield. Available at http://www.toponymie.gouv.qc.ca/ct/ToposWeb/Fiche.aspx?no_seq=11425 (accessed 10 ${ }^{\text {th }}$, October, 2018)

13. Core Team, R., 2014. R: A Language and Environment for Statistical Computing. Available at : http://www.rproject.org (accessed $10^{\text {th }}$, October, 2018).

14. Dalby, A.P., Kumar, A., Moore, J.M., Patterson, R.T., 2000. Utility of arcellaceans (thecamoebians) as paleolimnological indicators in tropical settings: Lake Sentani, Irian Jaya, Indonesia. J. Foraminiferal Res. 30:135-142.

15. Davies, P.H., Brinkman, S.F., 1994. "Acute and chronic toxicity of manganese to exposed and unexposed rainbow and brown trout". In Colorado Division of Wildlife. Water Pollution Studies Federal Aid Project \#F-243R-1.

16. Davidova, R., Vasilev, V.. 2013. Seasonal Dynamics of the Testate Amoebae Fauna (Protozoa: Arcellinida and Euglyphida) in Durankulak Lake (Northeastern Bulgaria). Acta Zool. Bulg. 65:27-36.

17. Delfino, J.J., Bortleson, G.C., Lee, G.F., 1968. Distribution of $\mathrm{Mn}, \mathrm{Fe}, \mathrm{P}, \mathrm{Mg}, \mathrm{K}, \mathrm{Na}$, and $\mathrm{Ca}$ in the Surface Sediments of Lake Mendota, Wisconsin. Environ. Sci. and Technol. 3:1189-1192.

18. Ehrenberg, C.G., 1830. Organisation, systematic und geographisches Verhältniss der Infusions-thierchen, Berlin. Druckerei der Königlichen Akademie der Wissenschaften 108

19. Ehrenberg, C.G., 1832. Über die Entwicklung und Lebensdauer der Infusionstiere, nebst ferneren Beiträgen zu einer Vergleichung ihrer organischen systeme. Abhandlungen der Akademie der Wissenschaften Berlin, 181.

20. Ehrenberg, C.G., 1840. Das grössere Infusorienwerke. Abh Akad Wiss Berlin 198-219

21. Ehrenberg, C.G., 1843. Verbreitung und Einfluss des mikroskopischen Lebens in Su"d-und Nord Amerika. Ko"nigliche Akademie der Wissenschaften zu Berlin Physikalische Abhandlungen 1841:291-446

22. Environment Canada., 2018a. Canadian Climate Normals: Wright. Available at http://climate.weather.gc.ca/climate_normals/results 19812010 e.html?searchType $=$ stnProv\&lstProvince 
$=\mathrm{QC} \&$ txtCentralLatMin $=0 \&$ txtCentralLatSec $=0 \&$ txtCentralLongMin $=0 \&$ txtCentralLongSec $=0 \& \operatorname{stn} I D=56$ 42\&dispBack $=0$ (accessed $10^{\mathrm{TH}}$, October 2018)

23. Environment Canada., 2018b. Canadian Climate Normals: Fredericton. Available at http://climate.weather.gc.ca/climate normals/results 19812010 e.html?stnID=6157\&lang=e\&province= NB\&provSubmit $=$ go\&dCode $=1\left(\right.$ accessed $10^{\mathrm{TH}}$, October 2018)

24. Fales, S.L., Ohki, K., 1982. Manganese deficiency and toxicity in wheat: influence on growth and forage quality of herbage. Agron. J. 74:1070-1073. https://doi.org/10.2134/agronj1982.00021962007400060033x

25. Farooqui, A., Gaur, A.S., 2007. Arcellaceans and pollen/spores of a late Harappan settlement near Porbandar, west coast of India: Implications for palaeoecology and environmental monitoring. Curr. Sci. 92(7):992-998.

26. Farooqui, A., Kumar, A., Swindles, G.T., 2012. Thecamoebian communities as proxies of seasonality in Lake Sadatal in the Ganga-Yamuna Plains of North India. Palaeontol. Electronica 15.1.3A:19.

27. Fishbein, E., Patterson, R.T., 1993. Error-weighted maximum likelihood (EWML): a new statistically based method to cluster quantitative micropaleontological data. J. Paleontol. 67:475-486. https://doi.org/10.1017/s0022336000036921

28. Foissner, W., 1994. High Numbers of Testate Amoebae (Protozoa) in Benthon of Clean, Acidified Mountain Streams. Limnologica 24(4):323-331.

29. Foissner, W., Schiller, W., 2001. Stable for 15 million years: scanning electron microscope investigation of Miocene euglyphid thecamoebians from Germany, with description of the new genus Scutiglypha. Eur. J. Protistol. 37:167-180. https://doi.org/10.1078/0932-4739-00012

30. Gavel, M.J., Patterson, R.T., Nasser, N.A., Galloway, J.M., Roe, H.M., Cott, P.A., Ellis, S., 2018. What killed Frame Lake? a precautionary tale for urban planners. PeerJ 6:e4850; DOI 10.7717/peerj.4850

31. Gauthier, M., Brown, A.C., 1986. Zinc and iron metallogeny in the Maniwaki-Gracefield district, southwestern Quebec. Econ. Geol. 81:89-112.https://doi.org/10.2113/gsecongeo.81.1.89

32. Hanson, R., 2014. Oromocto River Watershed Gaspereau Study. Parish Geomorphic Ltd. \& Oromocto River Watershed Association Inc.

33. Huang, C.G., MacDonald, G., Cwynar, L., 2004. Holocene landscape development and climatic change in the low arctic, northwest territories, Canada. Palaeogeogr. Palaeoclimatol. Palaeoecol. 205(3-4):221-34. https://doi.org/10.1016/j.palaeo.2003.12.009

34. Heiri, O., Lotter, A.F., Lemcke, G.. 2001. Loss on ignition as a method for estimating organic and carbonate content in sediments: reproducibility and comparability of results. J. Paleolimnol. 25(1):101-110. https://doi.org/10.1023/A:1008119611481

35. Hill, M.O., 1979. Decorana - A Fortran program for detrended correspondence analysis and reciprocal averaging. Ecology and Systematics, Cornell University, Ithaca, New York 14850:52.

36. Hotelling, H., 1933. Analysis of a Complex of Statistical Variables Into Principal Components. J. Educ. Psychol. 24:417-441 and 498-520. https://doi.org/10.1037/h0070888

37. Kihlman, S.M., Kauppila, T., 2009. Mine water-induced gradients in sediment metals and arcellacean assemblages in a boreal freshwater bay (Petkellahti, Finland). J. Paleolimnol. 42:533-550.

38. Kumar, A., Patterson, R.T., 2000. Arcellaceans (thecamoebians): new tools for monitoring long- and short-term changes in lake bottom acidity. Environ. Geol. 39:689-697.

https://doi.org/10.1007/s002540050483

39. Lamarck, J.B., 1816. Histoire Naturelle des Animaux sans Vèrtèbres. Verdièie, Paris tome 2, p. 1-568

40. Laminger, H., 1971. Sedimentbewohnenden Schalenamoben (Rhizopoda, Testacea) der Finstertaler Seen (Tirol). Arch. Hydrobiol. 69(1):106-140.

41. Laminger, H., Geisler-Moroder, K., Siess, A., Spiss, E., Spiss, B., 1980. Populationsdynamik terrestrischer Protozoen (Testacea, Rhizopoda) in Zentralalpinen Lagen Tirols. I. Untersuchungen subalpinen Boden in Raum Obergurgl (Tirol/Österreich). Arch. Protistenk. 123:280-323.

42. Leidy, J., 1874. Notice of some new freshwater rhizopods. J. Nat. Hist. 14(83): 383-385.

43. Levin, S., 1992. The problem of pattern and scale in ecology. Ecol. 73:1943-1967.

44. Lousier, J.D., 1984. Population dynamics and production studies of species of Nebelidae (Testacea, Rhizopoda) in an aspen woodland soil. Acta Protozool. 23:145-159.

45. Magurran, A.E., 1988. Ecological diversity and its measurement. Princeton University Press, Prinction, 185. 
46. Mazei, Y.A., Tsyganov, A.N., 2007. Species composition, spatial distribution and seasonal dynamics of testate amoebae community in a Sphagnum bog (Middle Volga region, Russia). Protistol. 5:156-206.

47. Medioli, F.S., Scott, D.B., 1988. Lacustrine thecamoebians (mainly Arcellaceans) as potential tools for palaeoclimatological interpretations. Palaeogeogr. Palaeoclimatol. Palaeoecol. 62(1-4):361-386. https://doi.org/10.1016/0031-0182(88)90062-4

48. Mitchell, E.A., Payne, R.J., Lamentowicz, M., 2008. Potential implications of differential preservation of testate amoeba shells for paleoenvironmental reconstruction in peatlands. J. Paleolimnol. 40(2):603-618. https://doi.org/10.1007/s10933-007-9185-z

49. Murray, A., 2002. Is laser particle size determination possible for carbonate-rich lake sediments? J. Paleolimnol. 27:173-183

50. NAS., 1977. Arsenic. Medical and Biologic Effects of Environmental Pollutants. National Academy of Sciences, Washington, D.C.

51. Nasser, N.A., Patterson, R.T., Roe, H.M., Galloway, J.M., Falck, H., Palmer, M.J., Spence, C., Sanei, H., Macumber, A.L., Neville, L.A., 2016. Lacustrine Arcellinina (testate amoebae) as bioindicators of arsenic contamination. Microb. Ecol. 72:130-149. https://doi.org/10.1007/s00248-016-0752-6

52. Neville, L.A., McCarthy, F.M.G., MacKinnon, M.D., 2010. Seasonal environmental and chemical impact on thecamoebian community composition in an oil sands reclamation wetland in northern Alberta. Paleontol. Electronica 13(2):14. https://palaeo-electronica.org/2010_2/231/index.html

53. Patterson, R.T., Baker, T., Burbridge, S.M., 1996. Arcellaceans (thecamoebians) as proxies of arsenic and mercury contamination in northeastern Ontario lakes. J Foramin Res 26:172-183

54. Patterson, R.T., Dalby, A., Kumar, A., Henderson, L.A., Boudreau, R.E., 2002. Arcellaceans (thecamoebians) as indicators of land-use change: settlement history of the Swan Lake area, Ontario as a case study. J. Paleolimnol. 28(3):297-316.

55. Patterson, R.T., Fishbein, E., 1989. Re-examination of the statistical methods used to determine the number of point counts needed for micropaleontological quantitative research. J. Paleontol. 63:245-248. https://doi.org/10.1017/s0022336000019272

56. Patterson, R.T., MacKinnon, K.D., Scott, D.B., Medioli, F.S., 1985. Arcellaceans (Thecamoebians) in small lakes of New Brunswick and Nova Scotia: modern distribution and Holocene stratigraphic changes. J. Foraminiferal Res. 15(2):114-137. https://doi.org/10.2113/gsjfr.15.2.114

57. Patterson, R.T., Kumar, A., 2002. A review of current testate rhizopod (thecamoebian) research in Canada. Palaeogeogr. Palaeoclimatol. Palaeoecol. 180(1):225-251. https://doi.org/10.1016/s00310182(01)00430-8

58. Patterson, R.T., Lamoureux, E.D., Neville, L.A., Macumber, A.L., 2013. Arcellacea (testate lobose amoebae) as $\mathrm{pH}$ indicators in a pyrite mine-acidified lake, Northeastern Ontario, Canada. Microb. Ecol. 65(3):541-554.

59. Patterson, R.T., Roe, H.M., Swindles, G.T., 2012. Development of an Arcellacean (testate lobose amoebae) based transfer function for sedimentary phosphorous in lakes. Palaeogeogr. Palaeoclimatol. Palaeoecol. 348-349:32-44. https://doi.org/10.1016/j.palaeo.2012.05.028

60. Patterson, R.T., Huckerby, G., Kelly, T.J., Swindles, G.T., Nasser, N.A., 2015. Hydroecology of Amazonian lacustrine Arcellinida (testate amoebae): A case study from Lake Quistococha, Peru. Eur. J. Protistol. 51: 460-469. https://doi.org/10.1016/j.ejop.2015.06.009

61. Pearson, K., 1901. On lines and planes of closest fit to systems of points in space. Philos. Mag. 2:559-572.

62. Penard, E., 1890. Catalog der nackten und schalentragenden Rhizopoden von Wiesbaden. Jarbuch der nassavischen Vereins für Naturkunde 43:67-72

63. Penard, E., 1902. Faune Rhizopodique du Bassin du Lèman. Henry Kündig, Libraire de L’institut, Genéve pp 712

64. Porter, S.A., Knoll, A.H., 2000. Testate amoeba in the Neoproterozpic Era: evidence from vase-shaped microfossils in the Chuar Group, Grand Canyon. J. Paleobiol. 26:360-385.

65. Pronk, A.G., Allard, S., 2003. Landscape map of New Brunswick. New Brunswick. Department of Natural Resources and Energy; Minerals, Policy and Planning Division, Map NR-9. (scale 1:770 000)

66. Rao, C.R., 1995. A review of canonical coordinates and an alternative to correspondence analysis using Hellinger distance. Qüestiió 19:23-63.

67. Reimann, C., Filzmoser, P., Garrett, R.G., Dutter, R., 2008. Statistical Data Analysis Explained: Applied Environmental Statistics with R. John Wiley \& Sons, Ltd. ISBN: 978-0-470-98581-6 
68. Reinhardt, E.G., Dalby, A.P., Kumar, A., Patterson, R.T., 1998. Arcellaceans as pollution indicators in mine tailing contaminated lakes near Cobalt, Ontario, Canada. Micropaleontol. 44:131-148. https://doi.org/10.2307/1486066

69. Robb, C., 1968. Report of Mr. Charles Robb addressed to Sir William Logan, F.R.S., F.G.S., Director of the Geological Survey in Report of Progress From 1866 to 1869 Accompanied by Geological and Topographical Maps, p. 173-209. Dawson Bros. Montreal

70. Roe, H.M., Patterson, R.T., 2006. Distribution of thecamoebians (testate amoebae) in small lakes and ponds, Barbados, West Indies. J. Foraminiferal Res. 36(2):116-134. https://doi.org/10.2113/36.2.116

71. Roe, H.M., Patterson, R.T., Swindles, G.T., 2010. Controls on the contemporary distribution of lake thecamoebians (testate amoebae) within the Greater Toronto Area and their potential as water quality indicators. J. Paleolimnol. 43(4):955-975. https://doi.org/10.1007/s10933-009-9380-1

72. Roe, H.M., Patterson, R.T., 2014. Arcellacea (testate amoebae) as bio-indicators of road salt contamination in lakes. Microb. Ecol. 68(2):299-313. https://doi.org/10.1007/s00248-014-0408-3

73. Sabina, A.P., 1970. Rock and Minerals for the collector, Hull-Maniwaki, Quebec; Ottawa-Peterborough, Ontario. Ottawa, Ontario: Geological Survey of Canada. https://doi.org/10.4095/103344

74. Santoro, A., Held, A., Linsinger, T.P.J., Perez, A., Ricci, M., 2017. Comparison of total and aqua regia extractability of heavy metals in sewage sludge: The case study of a certified reference material. Trends Anal. Chem. 89, 34-40. https://doi.org/10.1016/j.trac.2017.01.010

75. Schwind, L.T., Arrieira, R.L., Dias, J.D., Simões, N.R., Bonecker, C.C., Lansac-Tôha, F.A., 2015. The structure of planktonic communities of testate amoebae (Arcellinida and Euglyphida) in three environments of the Upper Paraná River basin, Brazil. J. Limnol. 75(1).

76. Schönborn, W., 1992. Comparative Studies on the Production Biology of Protozoan communities in Freshwater and soil Ecosystems. Arch. Protistenkd. 141:187-214.

77. Scott, D.B., Hermelin, J.O.R., 1993. A device for precision splitting of micropaleontological samples in liquid suspension. J. Paleontol. 67(01):151-154. https://doi.org/10.1017/s0022336000021302

78. Shannon, C.E., 1948. A mathematical theory of communication. AT\&T Technical Journal 27(379423):623-656.

79. Steele, R.E., Nasser, N.A., Patterson, R.T., Gregory, B.R., Roe, H.M., Reinhardt, E.G., 2018. An Assessment of Sub-Meter Scale Spatial Variability of Arcellinida (Testate Lobose Amoebae) Assemblages in a Temperate Lake: Implications for Limnological Studies. Microb. Ecol. 76:680-694. https://doi.org/10.1007/s00248-018-1157-5

80. Thrush, S.F., Schneider, D.C., Legendre, P., Whitlatch, R.B., Dayton, P.K., Hewitt, J.E., Hines, A.H., Cummings, V.J., Lawerie, S.M., Grant, J., Pridmore, R.D., Turner, S.J., McArdle, B.H., 1997. Scaling- up from experiments to complex ecological systems: where to next? J. Exp. Mar. Biol. Ecol. 216:343-254.

81. van den Wollenberg, A.L., 1977. Redundancy analysis. An alternative for canonical correlation analysis. Psychometrika 42:207-219. https://doi.org/10.1007/bf02294050

82. van Hengstum, P.J., Reinhardt, E.G., Medioli, F.S., Gröcke, D.R., 2007. Exceptionally preserved late Albian (Cretaceous) Arcellaceans (Thecamoebians) from the Dakota Formation near Lincoln, Nebraska, USA. J. Foraminiferal Res. 37:300-3008.

83. Vázquez-Riveiros, N.A., Babalola, A.O., Boudrea, R.A., Patterson, R.T., Roe, H.M., Doherty, C., 2007. Modern distribution of saltmarsh foraminifera and thecamoebians in the Seymour-Belize Inlet Complex, British Columbia, Canada. Quaternary Land-Ocean Interactions: Sea-Level Change, Sediments and Tsunami. Mar. Geol. 242 (1-3): 39-63. https://doi.org/10.1016/j.margeo.2006.08.009

84. Wallich, G.C., 1864. On the process of mineral deposit in the rhizopods and sponges, as affording a distinctive character, Ann. Mag. Nat. Hist. Ser 3, 13:72-82

85. Ward, J.H., 1963. Hierarchical grouping to optimize an objective function. J. Am. Stat. Assoc. 58: 236244. https://doi.org/10.2307/2282967 